\title{
EVALUASI TATA KELOLA NILAI INVENTASI TEKNOLOGI INFORMASI MENGGUNAKAN DOMAIN VALUE GOVERNANCE DALAM KERANGKA KERJA VAL IT 2.0 (STUDI KASUS: POLITEKNIK LP3I BANDUNG)
}

\author{
Agus Salim, S.Kom., M.Kom. \\ Dosen Program Studi Manajemen Informatika \\ Politeknik LP3I Bandung \\ Email : agussalim87@gmail.com
}

\begin{abstract}
Abstrak : Penerapan teknologi informasi dalam menjalankan strategi bisnis dalam suatu perusahaan di era informasi saat ini sangat diperlukan dalam rangka memberikan nilai layanan dan juga dalam mempertahankan keberadaan perusahaan terhadap persaingan dengan perusahaan sejenis. Investasi teknologi informasi merupakan hal yang wajib dilakukan perusahaan untuk dapat mendukung strategi perusahaan dengan cara membantu perusahaan dalam mendapatkan efisiensi dan efektifitas operasional, meningkatkan proses perencanaan dan membuka pasar baru. Dalam penelitian ini dilakukan analisis tentang penggunaan framework Val IT 2.0 dengan menggunakan salah satu domain yaitu Value Governance dalam mengukur nilai manfaat investasi teknologi informasi berdasarkan tata cara pengelolaan nilai manfaat dari sebuah investasi teknologi informasi. Penelitian ini dilakukan dengan studi kasus di Politeknik LP3I Bandung. Penelitian ini menggunakan instrumen kuesioner yang diberikan kepada jajaran manajemen dan staf yang terlibat dalam penggunaan sistem informasi di Politeknik LP3I Bandung. Analisis yang dihasilkan juga disertai pengukuran tingkat maturitas dari domain Value Governance dari kerangka kerja Val IT 2.0, sehingga Politeknik LP3I Bandung dapat memiliki gambaran tentang proses-proses manajemen nilai investasi TI yang membutuhkan pengembangan lebih lanjut. Berdasarkan hasil penelitian yang dilakukan diketahui bahwa sebagian besar tingkat kematangan berada pada level 3 (defined). Politeknik LP3I Bandung telah menjalankan proses investasi TI sebagai bagian penting dari tujuan organisasi, adanya kajian pengelolaan investasi TI dengan menggunakan framework Val IT 2.0 dapat membuat Politeknik LP3I Bandung menyadari keunggulan-keunggulan yang dapat dipertahankan dan kekurangankekurangan yang harus diperbaiki terkait pengelolaan investasi TI.
\end{abstract}

Kata Kunci : Nilai Investasi TI, Val IT 2.0, Tata Kelola Nilai Investasi TI, Tingkat Kematangan

\section{Pendahuluan}

Penerapan teknologi informasi dalam menjalankan strategi bisnis dalam suatu perusahaan di era informasi saat ini sangat diperlukan dalam rangka memberikan nilai layanan dan juga dalam mempertahankan keberadaan perusahaan terhadap persaingan dengan perusahaan sejenis. Penerapan sistem informasi dapat 
menambah nilai proses bisnis yang dilakukan perusahaan dalam memberikan pelayanan baik terhadap pelanggan atapun ke stakeholders lainnya yang memiliki kepentingan terhadap perusahaan tersebut. Dengan adanya sistem informasi maka dibutuhkan juga teknologi informasi yang tepat untuk mendukung kebutuhan dari sistem informasi yang diterapkan sehingga teknologi informasi dapat mendukung sistem informasi dengan efektif.

Investasi teknologi informasi merupakan segmen yang cukup menguras biaya, dikarenakan investasi teknologi informasi tidak hanya dihitung dari biaya pengadaan saja, akan tetapi dilanjutkan dengan biaya pemeliharaan selama investasi tersebut digunakan. Investasi teknologi informasi sangat berbeda dengan jenis investasi lainnya seperti investasi tanah, gedung dan peralatan kantor karena nilai investasi tidak berkurang nilainya seiring berjalannya waktu. Hal ini disebabkan karena investasi teknologi informasi dapat menghasilkan manfaat terhitung (tangible) dan manfaat tidak terhitung (intangible). Investasi teknologi informasi memerlukan biaya, untuk itu diharapkan investasi teknologi informasi mendatangkan keuntungan secara nyata, keuntungan ini bukan hanya dilihat dari sisi teknologinya seperti: hardware dan software, akan tetapi harus juga memberi tambahan nilai terhadap proses bisnis yang dilakukan perusahaan sehingga dapat memberikan layanan produk yang maksimal. Oleh karena itu diperlukan beberapa pertimbangan yang harus dilakukan dalam melakukan investasi terhadap teknologi informasi diantaranya adalah seberapa jauh nilai manfaat investasi teknologi informasi dapat memberikan kontribusi terhadap kinerja bisnis perusahaan dan seberapa besar nilai keuntungan dari investasi teknologi informasi yang diterapkan. Pengukuran nilai investasi teknologi informasi yang telah dilakukan merupakan bagian dari tanggung jawab manajemen TI.

Politeknik LP3I Bandung merupakan perguruan tinggi berbasis vokasi yang berdiri pada tahun 2001, pada 9 tahun terakhir Politeknik LP3I Bandung telah melakukan investasi pada teknologi informasi untuk mendukung kinerja dari bisnis yang sedang dijalankan. Investasi teknologi informasi yang dilakukan Politeknik LP3I Bandung dengan menerapkan sistem informasi yang terintegrasi dari satu bagian ke bagian lainnya diharapkan dapat memberikan nilai kontribusi yang baik terhadap pelayanan yang diberikan kepada seluruh stakeholder dan juga dapat menambah keunggulan strategis perusahaan dalam mempertahankan keunggulan dari para pesaing.

Akan tetapi, dari perkembangan penerapan TI di Politeknik LP3I Bandung tersebut, pihak manajemen belum dapat mendapatkan gambaran seberapa besar nilai kontribusi dari penerapan teknologi informasi terhadap nilai strategis bisnis perusahaan. Pada kenyataannya bahwa dilihat dari tren penerimaan mahasiswa baru selama 5 tahun terakhir ini, Politeknik LP3I Bandung malah menurun. Berikut adalah data tren penerimaan mahasiswa baru di Politeknik LP3I Bandung selama 5 tahun terakhir:

Untuk memperoleh nilai manfaat dan kontribusi investasi teknologi informasi terhadap strategi bisnis perusahaan kerangka kerja yang dapat menghitung nilai keuntungan investasi teknologi informasi. Val IT adalah salah satu kerangka kerja 
yang dapat memberikan gambaran jelas mengenai keuntungan aset teknologi informasi pada suatu organisasi. Berdasarkan uraian permasalahan yang telah dipaparkan di atas, maka penulis membuat tesis dengan judul "EVALUASI TATA KELOLA NILAI INVESTASI TEKNOLOGI INFORMASI MENGGUNAKAN DOMAIN VALUE GOVERNANCE DALAM KERANGKA KERJA VAL IT 2.0 (Studi Kasus: Politeknik LP3I Bandung)", melalui penelitian ini, diharapkan dapat membantu agar investasi teknologi informasi dapat berjalan dengan baik dan selaras dengan strategi bisnis perusahaan sehingga dapat meningkatkan nilai bisnis Politeknik LP3I Bandung.

\section{Tinjauan Pustaka}

Bab ini menjelaskan teori dan proses manajemen investasi teknologi menggunakan framework VAL IT 2.0 dalam melakukan penilaian terhadap investasi IT.

\subsection{Kerangka Kerja Val IT Framework 2.0}

Val IT diprakasai oleh Information Technology Governance Institute (ITGI) melalui masukan-masukan dari para pimpinan, praktisi, sekumpulan tim yang tergabung pada komunitas IT. Val IT menyedikan sebuah pelayanan, penelitian, publikasi dan pendukung-pendukung untuk membantu organisasi dalam melakukan penilaian investasi IT, yang bertujuan untuk membantu organisasi untuk merealisasikan secara optimal investasi TI yang diterapkan pada organisasinya (Latulipe, 2007:2).

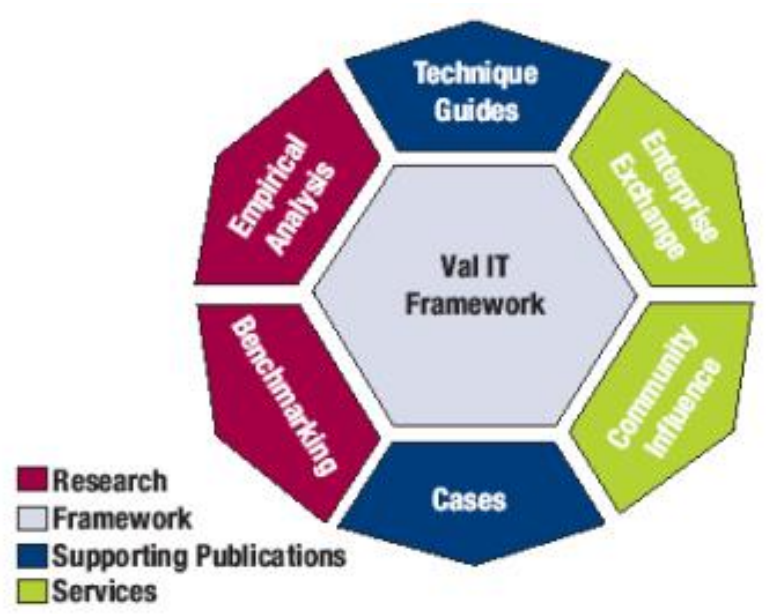

Gambar 2.1 Inisiatif Val IT Framework (ITGI, 2008:6)

Berdasarkan gambar 2.1 Val IT memberikan pedoman proses-proses dan dukungan praktis untuk membantu pimpinan dan manajemen eksekutif dalam memahami dan melaksanakan peran yang sesuai dalam merencanakan investasi teknologi informasi. Organisasi dapat menggunakan prinsip-prinsip, prosesproses, dan hal-hal praktis yang terdapat di Val IT untuk memperoleh manfaat strategik dan menciptakan level bisnis nyata yang lebih berarti. 
Manfaat yang diperoleh dengan menggunakan kerangka kerja Val IT Framework menurut (Witanti, 2007; I-33) adalah:

1. Meningkatkan pemahaman dan transparansi atas biaya, resiko, dan manfaat yang dihasilkan dari keputusan manajjmen yang dilandasi oleh informasi yang memadai.

2. Meningkatkan kemampuan memilih investasi yang memiliki potensial pengembalian manfaat terbesar.

3. Meningkatkan kecenderungan keberhasilan dalam menjalankan investasi yang dipilih sehingga investasi tersebut dapat menghasilkan manfaat sesuai yang diharapkan.

4. Mengurangi biaya dengan hanya mengerjakan apa yang seharusnya dikerjakan dan segera mengambil tindakan korektif atau menghentikan investasi yang tidak menghasilkan potensi manfaat yang diharapkan.

5. Mengurangi resiko kegagalan, khususnya kegagalan yang beresiko tinggi.

6. Mengurangi 'kejutan' yang berhubungan dengan biaya dan delivery TI, sehingga dapat meningkatkan nilai bisnis, mengurangi biaya yang tidak perlu dan meningkatkan kepercayaan terhadap IT secara keseluruhan

Val IT dapat diterapkan pada investasi TI yang mendukung bisnis, keberlanjutan investasi bisnis, pertumbuhan atau transformasi bisnis dengan dukungan komponen TI yang kritikal dimana TI memberikan dukungan penuh secara endto-end terhadap seluruh proses penciptaan nilai di perusahaan.

\subsection{Prinsip-Prinsip Val IT}

Prinsip-prinsip Val IT menurut (ITGI, 2008:11) adalah sebagai berikut:

1. Investasi-investasi TI akan dikelola sebagai portofolio investasi. Untuk mengoptimalkan investasi membutuhkan kemampuan untuk mengevaluasi dan membandingkan investasi, memilih investasi secara obyektif dengan potensi tertinggi untuk menciptakan nilai, dan mengelola semua investasi untuk memaksimalkan nilai dari investasi tersebut

2. Investasi-investasi TI akan meliputi seluruh aktivitas yang diperlukan untuk mencapai nilai bisnis. Nilai investasi TI membutuhkan lebih dari hanya memberikan solusi dan layanan TI, tapi juga harus memberikan perubahan terhadap beberapa hal berikut: sifat dari bisnis itu sendiri; proses bisnis, keterampilan dan kompetensi; dan organisasi, yang semuanya harus disertakan dalam business case untuk investasi tersebut.

3. Investasi-investasi TI akan dikelola melalui seluruh siklus hidup ekonomi investasi tersebut.

Business case harus tetap berjalan dari awal inisiasi investasi sampai layanan TI yang dihasilkan tidak lagi digunakan (retire). Prinsip ini mengakui bahwa akan selalu ada beberapa tingkat ketidakpastian dan variabilitas dari waktu ke waktu dalam biaya, risiko, manfaat, strategi, dan organisasi serta perubahan eksternal harus diperhitungkan dalam menentukan apakah pendanaan harus dilanjutkan, meningkat, menurun atau berhenti.

4. Kaidah pemberian nilai akan menunjukkan adanya perbedaan katagori investasi yang akan dievaluasi dan dikelola secara berbeda. Beberapa kategori mungkin saja didasarkan pada kebijakan manajemen, besarnya biaya, jenis 
risiko, pentingnya manfaat (misalnya, pencapaian kepatuhan terhadap peraturan), jenis dan luasnya perubahan bisnis.

5. Kaidah pemberian nilai akan menjelaskan dan memonitor matrik utama dan akan memberikan respon yang cepat terhadap segala perubahan atau penyimpangan. Matrik harus dilakukan dan dipantau secara teratur untuk memastikan nilai yang diciptakan dan terus dibuat sepanjang siklus hidup investasi.

6. Kaidah pemberian nilai akan melibatkan seluruh stakeholder dan memberikan akuntabilitas yang tepat bagi penyampaian kapabilitas serta realisasi dari keuntungan bisnis. Fungsi TI dan bagian-bagian lain dari bisnis harus saling terikat akuntabel. Fungsi TI untuk kemampuan TI dan proses bisnis untuk kemampuan bisnis yang diperlukan untuk mewujudkan nilai.

7. Kaidah pemberian nilai akan di pantau, di evaluasi dan ditingkatkan secara berkelanjutan. Sebagai perusahaan yang mendapatkan pengalaman dengan praktik Val IT, pembelajaran dapat diterapkan sehingga proses pemilihan investasi dan pengelolaan investasi TI dapat meningkat setiap tahun

\subsection{Proses-Proses Val IT Framework}

Proses adalah kumpulan aktivitas yang saling berinteraksi yang dilakukan sesuai dengan praktek manajemen. Proses mengambil masukan dari satu atau lebih banyak sumber (termasuk proses lainnya), memanipulasi masukan, memanfaatkan sumber daya sesuai dengan kebijakan, dan menghasilkan output (termasuk output ke proses lainnya). Proses harus memiliki alasan bisnis yang jelas untuk, pemilik akuntabel, peran yang jelas dan tanggung jawab yang ada sekitar pelaksanaan setiap proses, dan sarana untuk melakukan dan mengukur kinerja (ITGI, 2008:15). Proses Val IT dapat diilustrasikan pada gambar 2.2.

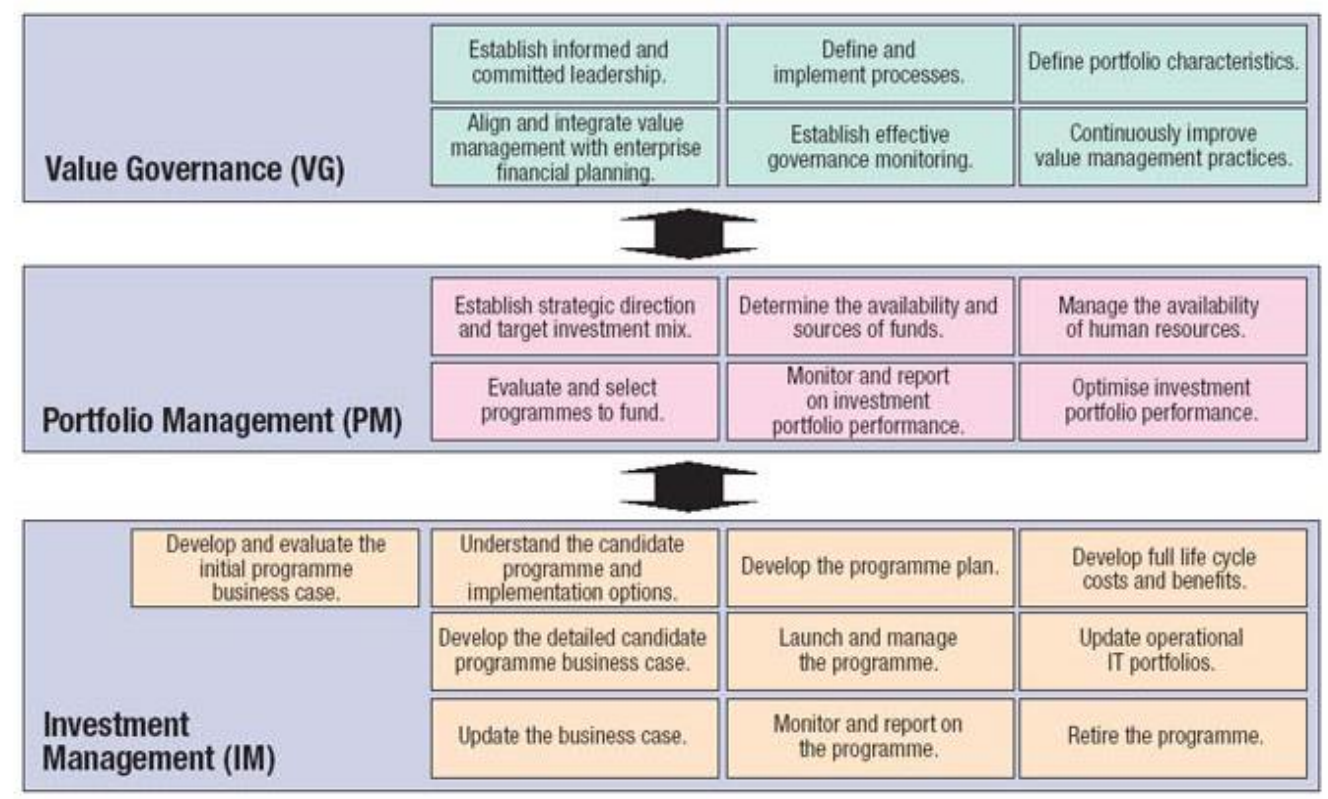

Gambar 2.2 Domain dan Proses Val IT Framework 2.0 (ITGI, 2008:15) 
Untuk memperoleh pengembalian investasi, dasar dari Val IT diterapkan oleh stakeholder melalui proses-proses berikut (ITGI, 2008:12):

1. Value Governance (VG)

Sasaran Value Governance adalah mengoptimalkan nilai dari sebuah investasi berbasis IT dengan cara.

a. Menetapkan kerangka tata kelola pengelolaan nilai terintegrasi sepenuhnya dengan tata kelola perusahaan.

b. Memberikan arahan strategis untuk menentukan keputusan investasi

c. Menentukan karakteristik portofolio yang diperlukan untuk mendukung investasi dan layanan TI, asset dan sumber daya lainnya.

d. Meningkatkan nilai manajemen secara terus menerus, berdasarkan pembelajaran proses investasi TI yang didapat.

Proses-proses Value Governace terdiri dari 6 proses antara lain:

a. VG1 Establish informed and committed leadership, yaitu menetapkan pemberitahuan informasi tentang Investasi TI dan terlaksananya kepimpinan.

b. VG2 Define and implement processes, yaitu mendefinisikan kebutuhan proses investasi TI dan mengimplementasikan proses-proses.

c. VG3 Define portfolio characteristics, yaitu mendefinisikan karakteristik portofolio investasi TI.

d. VG4 Align and integrate value management with enterprise financial planning, yaitu meluruskan dan mengintegrasikan nilai manajemen dengan perencanaan keuangan organisasi.

e. VG5 Establish effective governance monitoring, yaitu mengidentifikasi kunci dari tujuan proses nilai manajemen untuk diawasi secara efektif dan dilaporkan.

f. VG6 Continuously improve value management practices, yaitu meningkatkan secara berkala tentang proses nilai manajemen.

\section{Portfolio Management (PM)}

Sasaran Portfolio Management (PM) adalah untuk memastikan bahwa semua portofolio investasi TI selaras dan memberikan kontribusi optimal terhadap sasaran strategis organisasi dengan cara:

a. Penerapan dan mengelola profil sumber daya.

b. Pendefinisian awal investasi.

c. Mengevaluasi, prioritasi dan memilih, menunda atau menolak investasi baru

d. Pengelolaan portofolio secara menyeluruh.

e. Pemantauan dan mengevaluasi kinerja portofolio.

Proses - proses Portfolio Management (PM) terdiri dari 6 proses antara lain:

a. PM1 Establish strategic direction and target investment mix, yaitu menentukan arah tujuan strategis, dan target investasi.

b. PM2 Determine the availability and sources of funds, yaitu menentukan ketersediaan dan sumber dana untuk investasi TI.

c. PM3 Manage the availability of human resources, yaitu mengelola ketersediaan sumber daya manusia. 
d. PM4 Evaluate and select programmes to fund, yaitu mengevaluasi dan memilih program untuk didanai.

e. PM5 Monitor and report on investment portfolio performance, yaitu memantau dan melaporkan portofolio investasi.

f. PM6 Optimise investment portfolio performance, yaitu mengoptimalkan kinerja portofolio investasi.

\section{Investment Management (IM)}

Sasaran Investment Management memastikan program investasi berbasis IT sebuah organisasi menghasilkan nilai optimal dengan biaya yang terjangkau dan tingkat resiko yang dapat diterima dengan cara:

a. Identifikasi kebutuhan bisnis.

b. Membangun pemahaman yang jelas atas kandidat program investasi.

c. Pelaksanaan analisis alternativ untuk melaksanakan program.

d. Mendefinisikan program dan mendokumentasikan sebuah Business Case secara rinci termasuk menguraikan secara jelas dan terinci termasuk detail manfaatnya pemberian tanggung jawab dan portofolio yang jelas.

e. Menetapkan akuntabilitas yang jelas dan kepemilikan, termasuk untuk merealisasikan keuntungan.

f. Pengelolaan program melalui siklus hidup ekonomi yang penuh.

g. Memantau dan melaporkan kinerja program.

Proses-proses Investment Management terdiri dari 10 proses antara lain:

a. IM1 Develop and evaluate the initial programme concept Business Case, yaitu mengembangkan dan mengevaluasi konsep program permasalahan bisnis.

b. IM2 Understand the candidate programme and implementation options, yaitu memahami kandidat program dan memilih implementasi program.

c. IM3 Develop the programme plan, yaitu mengembangkan rencana program.

d. IM4 Develop full life-cycle costs and benefits, yaitu mengembangkan biaya siklus hidup dan manfaat yang dapat dicapai.

e. IM5 Develop the detailed candidate programme Business Case, yaitu mengembangkan program Business Case yang terperinci.

f. IM6 Launch and manage the programme, yaitu melaksanakan dan mengelola program.

g. IM7 Update operational IT portfolios, yaitu melakukan pembaharuan operasional portofolio TI.

h. IM8 Update the Business Case, yaitu melakukan pembaharuan Business Case.

i. IM9 Monitor and report on the programme, yaitu memantau dan melaporkan kinerja program.

j. IM10 Retire the programme, yaitu tahap akhir program.

Proses-proses diatas merupakan proses yang utama dalam Val IT

Framework oleh karena itu Value Governance, Portfolio Management dan Investment Management mempunyai Detailed Key Management Practices yang meliputi proses-proses yang lebih detail, hal itu dijelaskan pada lampiran. 


\subsection{Maturity Model Val IT}

Model kematangan proses Val IT membedakan tingkat kematangan menjadi 6 skala kematangan sebagai berikut ini:

1. Level 0 (Non-Existent): Proses belum dikenali secara utuh. Organisasi belum mengenal adanya isu atau permasalahan yang harus diselesaikan.

2. Level 1 (Initial): Organisasi telah mengenal isu atau masalah yang ada dan perlu diarahkan. Tidak ada proses standarisasi, tetapi sekurang-kurangnya ada pendekatan khusus (ad hoc) yang cenderung diterapkan pada individu atau dasar kasus demi kasus. Pendekatan terhadap keseluruhan manajemen tidak terorganisir.

3. Level 2 (Repeatable): Proses telah berkembang pada tahap di mana prosedur yang sama diikuti oleh orang yang berbeda dalam menjalankan tugas yang sama, tetapi tidak ada pelatihan formal atau prosedur komunikasi standar. Tanggung jawab diserahkan kepada setiap individu. Kepercayaan terhadap pengetahuan individu sangat tinggi sehingga seringkali terjadi kesalahan.

4. Level 3 (Defined): Prosedur telah distandarisasi, didokumentasikan dan dikomunikasikan melalui pelatihan, tetapi implementasinya masih bergantung pada individu dalam hal ketaatan terhadap prosedur. Prosedur dikembangkan sebagai bentuk formalisasi dari praktek yang ada.

5. Level 4 (Managed): Proses telah memungkinkan untuk memantau dan mengukur ketaatan pada prosedur sehingga dengan mudah diambil tindakan apabila proses yang ada tidak berjalan secara efektif. Perbaikan proses dilakukan secara kontinyu dan memberikan best practices. Otomatisasi dan peralatan yang digunakan masih terbatas.

6. Level 5 (Optimized): Proses telah di seleksi pada tingkat best practices berdasarkan hasil perbaikan yang terus menerus dan pengukuran model maturity dengan organisasi lain. TI digunakan secara terintegrasi untuk mengotomatisasi arus kerja, menyediakan alat untuk meningkatkan kualitas dan efektifitas dan membuat perusahaan mudah untuk beradaptasi.

Analisis tingkat Maturity Proses Val IT dilakukan apabila telah terpenuhinya perhitungan proses dari survei dan kuisioner, dikarenakan tingkatan level dari kematangan proses Val IT dapat digunakan untuk menilai proses Val IT apakah sangat baik atau tidak ada proses yang dijalankan. 


\section{Metode penelitian}

Tahapan penelitian yang dilakukan digambarkan dalam gambar 3.1.

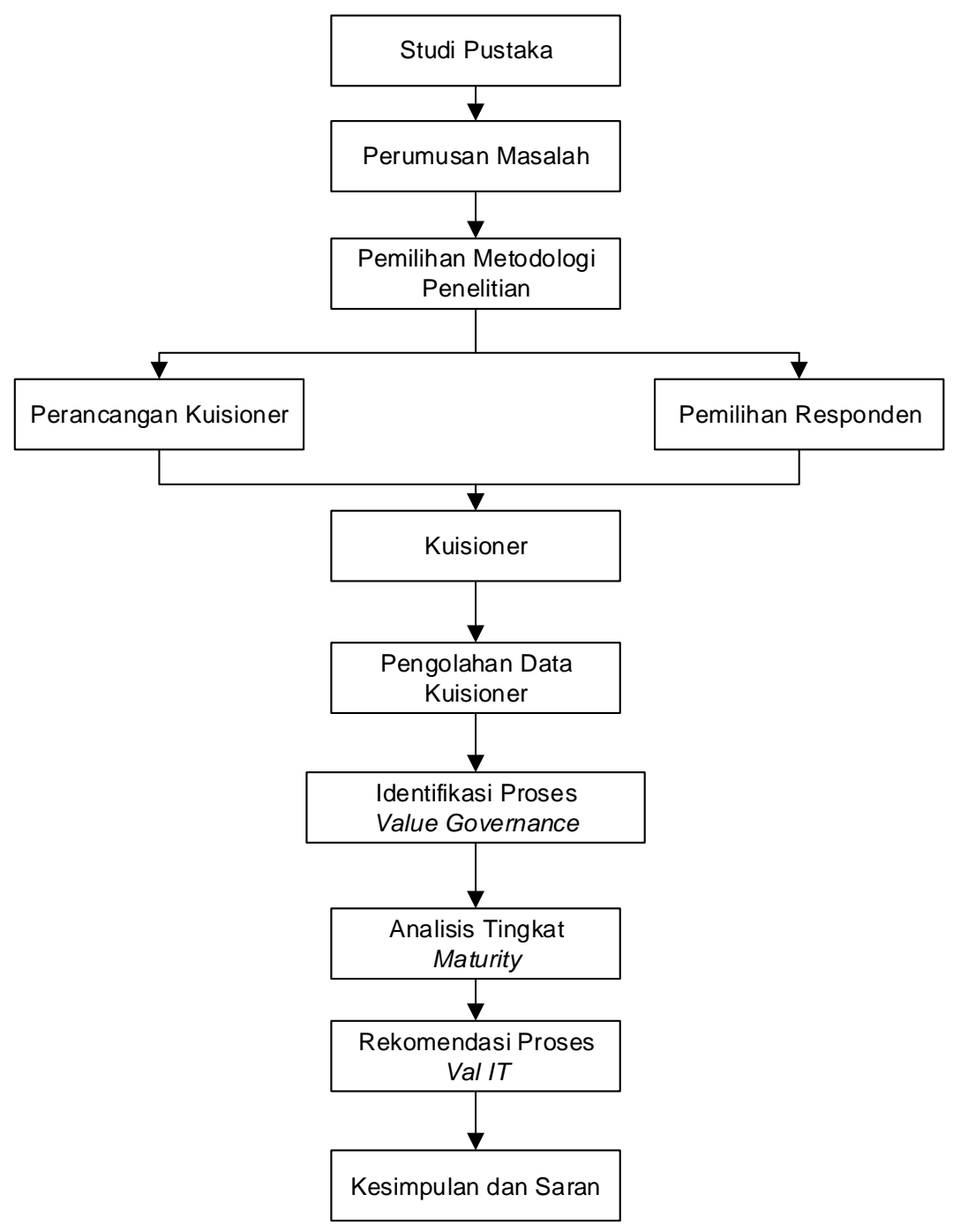

Gambar 3.3 Tahapan Penelitian

Adapun penjelasan dari tahapan-tahapan yang digambarkan pada gambar 3.1 adalah sebagai berikut:

1. Studi Pustaka

Melakukan studi untuk mempelajari penelitian sebelumnya, literatur-literatur yang berhubungan dengan pengelolaan investasi TI. Studi pustaka dilakukan melalui buku referensi, internet, jurnal dan sumber-sumber lainnya yang relevan dengan penelitian yang penulis lakukan.

2. Perumusan Masalah

Merumuskan permasalahan yang ada di Politeknik LP3I Bandung yang sudah dijelaskan pada Pendahuluan. 
3. Pemilihan Metode Penelitian

Pemilihan metode penelitian ditentukan dengan menggunakan kerangka kerja Val IT yang dikeluarkan oleh IT Governance Institute dan dengan melakukan survey pada perusahaan dengan menggunakan metode kuesioner

4. Perancangan Kuisioner

Perancangan kuesioner dilakukan dengan berpedoman pada Detailed Key Management Practices dan Maturity Model Val IT yaitu dengan melihat nilainilai untuk menentukan tingkat maturity. Pertanyaan kuisioner menjelaskan setiap proses Val IT yang dilakukan oleh pihak Politeknik LP3I Bandung berdasarkan jawaban Ya atau Tidak dan seberapa besar tingkat kematangan dari setiap pertanyaan mulai dari skala 1 sampai 5.

5. Pemilihan Responden

Pemilihan Responden dilakukan pada Politeknik LP3I Bandung, responden yang dipilih dalam penelitian ini adalah staf dan manajemen menengah dan atas yang berinteraksi langsung dengan sistem informasi yang diterapkan di Politeknik LP3I Bandung.

6. Kuesioner

Membagikan kuesioner terhadap responden yang telah dipilih dan mengumpulkan hsail kuesioner yang telah diisi oleh reponden

7. Pengolahan Data Kuesioner

Pengolahan data kuisioner dilakukan dengan mengolah data kuesioner dengan mencari nilai rata-rata setiap Key Management Practices Val IT.

8. Identifikasi Proses Val IT

Melakukan proses identifikasi salah satu domain Val IT yaitu Domain Value Governance untuk terhadap kondisi terakhir perusahaan dalam hal tata kelola nilai dan manfaat IT terhadap tujuan strategis perusahaan. Proses Identifikasi Val IT menghasilkan gambaran nilai maturity dari pengelolaan TI perusahaan. Hasil identifikasi memperlihatkan sejauh mana tata kelola TI sudah dilakukan dan sebesar apa nilai investasi TI terhadap nilai strategis perusahaan.

9. Analisis Tingkat Maturity Proses Val IT

Analisis tingkat Maturity Proses Val IT dilakukan setelah telah terpenuhinya perhitungan proses kuisioner, dikarenakan tingkatan level dari kematangan proses Val IT dapat digunakan untuk menilai proses Val IT apakah sangat baik atau tidak ada proses yang dijalankan.

10. Rekomendasi Proses Val IT

Berdasarkan peingidentifkasian proses - proses Val IT Politeknik LP3I Bandung maka diusulkan beberapa hal yang harus dilakukan untuk melaksanakan setiap proses Val IT diusulkan bagi peningkatan maturity level agar dapat mencapai tingkat 5 (Optimised) dan usulan perencanaan investasi teknologi informasi berdasarkan hasil analisis Business Case.

11. Kesimpulan dan Saran

Tahap akhir dalam penelitian ini adalah membuat kesimpulan. Setelah seluruh proses selesai, akan dilakukan evaluasi terhadap temuan-temuan dalam penelitian, serta memberikan saran-saran yang bisa digunakan untuk penelitian selanjutnya 


\section{Pemilihan Responden}

Dalam penelitian ini penulis menggunakan sampling sebanyak 70 orang dari seluruh populasi sebanyak 99 orang karyawan Politeknik LP3I Bandung. Adapun populasi karyawan Politeknik LP3I Bandung dijelaskan pada tabel 3.1.

Tabel 3.1 Populasi Karyawan Politeknik LP3I Bandung

\begin{tabular}{|l|r|r|}
\hline \multicolumn{1}{|c|}{ Level manajemen } & \multicolumn{1}{|c|}{ Jumlah } & Persentase \\
\hline $\begin{array}{l}\text { Manajemen tingkat tinggi (Direktur dan Wakil } \\
\text { Direktur) }\end{array}$ & 4 & $4 \%$ \\
\hline $\begin{array}{l}\text { Manajemen tingkat menengah (Dosen, Kepala } \\
\begin{array}{l}\text { Program Studi, Kepala Bagian dan Kepala Sub } \\
\text { Bagian) }\end{array}\end{array}$ & 41 & $41 \%$ \\
\hline Manajemen tingkat bawah (Staf) & 54 & $55 \%$ \\
\hline Total & $\mathbf{9 9}$ & $\mathbf{1 0 0 \%}$ \\
\hline
\end{tabular}

Responden merupakan staf dari beberapa unit kerja yang berkaitan langsung dengan Sistem Informasi Akademik dan level manajemen menengah serta level pimpinan karena dianggap yang paling memahami mengenai kebijakan investasi pada perusahaan. Adapun rincian jumlah responden dijelaskan pada tabel 3.2.

Tabel 3.2 Responden di Politeknik LP3I Bandung

\begin{tabular}{|l|r|r|}
\hline \multicolumn{1}{|c|}{ Level manajemen } & Jumlah & Persentase \\
\hline $\begin{array}{l}\text { Manajemen tingkat tinggi (Direktur dan Wakil } \\
\text { Direktur) }\end{array}$ & 4 & $11 \%$ \\
\hline $\begin{array}{l}\text { Manajemen tingkat menengah (Dosen, Kepala } \\
\text { Program Studi, Kepala Bagian dan Kepala Sub } \\
\text { Bagian) }\end{array}$ & 35 & $50 \%$ \\
\hline $\begin{array}{l}\text { Manajemen tingkat bawah (Staf yang berinteraksi } \\
\text { langsung terhadap teknologi informasi) }\end{array}$ & 31 & $44 \%$ \\
\hline Total & $\mathbf{7 0}$ & $\mathbf{1 0 0 \%}$ \\
\hline
\end{tabular}

\section{Analisis Identifikasi Proses Value Governance VAL IT}

Untuk mendapatkan hasil identifikasi proses Valuie Governance Val IT yang diterapkan oleh Politeknik LP3I Bandung, terlebih dahulu dilakukan survey menggunakan kuesioner. Proses penyebaran kuesioner dilakukan kepada 70 (tujuh puluh) responden. Hasil perhitungan kuesioner digunakan untuk menentukan tingkat model maturity dari masing-masing proses yang ada pada domain Value Governance Val IT dengan menggunakan skala pembulatan indeks yang ada pada tabel sebelumnya. 
Tabel 4.3 Identifikasi Proses Value Governance dari Val IT 2.0

\begin{tabular}{|c|l|c|c|}
\hline No & \multicolumn{1}{|c|}{ Proses Val IT } & Indeks & $\begin{array}{c}\text { Tingkat } \\
\text { Kematangan }\end{array}$ \\
\hline $\begin{array}{c}\text { VG.1 Menetapkan pemberitahuan informasi tentang Investasi TI dan } \\
\text { komitmen pimpinan }\end{array}$ & Level 3 \\
\hline 1 & $\begin{array}{l}\text { Apakah semua pimpinan di Politeknik LP3I } \\
\text { Bandung sudah paham bahwa TI merupakan } \\
\text { potensi strategis perusahaan? }\end{array}$ & 3,7 & Level 3 \\
\hline 2 & $\begin{array}{l}\text { Apakah aturan atau tata cara pelaporan yang } \\
\text { terkait dengan TI sudah dilakukan secara } \\
\text { efektif? }\end{array}$ & 3,8 & Level 3 \\
\hline 3 & $\begin{array}{l}\text { Apakah sudah membentuk forum } \\
\text { kepemimpinan tentang investasi TI beserta } \\
\text { tanggung jawabnya? }\end{array}$ & 3,5 & Level 3 \\
\hline 4 & $\begin{array}{l}\text { Apakah ada pemahaman yang jelas tentang } \\
\text { nilai investasi TI? }\end{array}$ & 3,7 & Level 3 \\
\hline 5 & $\begin{array}{l}\text { Apakah kepastian keselarasan dan integrasi } \\
\text { strategi institusi dan strategi TI } \\
\text { dikomunikasikan secara rutin? }\end{array}$ & 3,7 & $\begin{array}{c}\text { Level 3 } \\
\text { (Defined) }\end{array}$ \\
\hline \multicolumn{2}{|l|}{ Nilai Indeks VG1 adalah (3,7+3,8+3,5+3,7+3,7)/5=3,7} \\
\hline
\end{tabular}

VG.2 Mendefinisikan kebutuhan proses investasi TI dan mengimplementasikan proses-proses

\begin{tabular}{|c|c|c|c|}
\hline 6 & $\begin{array}{l}\text { Apakah sudah ditentukan kerangka kerja tata } \\
\text { kelola investasi TI secara konsisten ?? }\end{array}$ & 3.6 & Level 3 \\
\hline 7 & $\begin{array}{l}\text { Apakah dilakukan penilaian terhadap kualitas } \\
\text { proses strategi TI saat ini ? }\end{array}$ & 3.6 & Level 3 \\
\hline 8 & $\begin{array}{l}\text { Apakah prioritas investasi TI sudah } \\
\text { dilakukan dalam kerangka keseluruhan } \\
\text { perencanaan di Politeknik LP3I Bandung? }\end{array}$ & 3.9 & Level 3 \\
\hline 9 & $\begin{array}{l}\text { Apakah telah dilakukannya pendefinisian, } \\
\text { pengimplementasian yang secara konsisten } \\
\text { dari tujuan yang strategis pada Politeknik } \\
\text { LP3I Bandung? }\end{array}$ & 3.4 & Level 3 \\
\hline 10 & $\begin{array}{l}\text { Apakah telah dilakukan pendefinisian, } \\
\text { pengimplementasian, dan komunikasi atas } \\
\text { peran, tanggungjawab dan akuntanbilitas bagi } \\
\text { semua personel di Politeknik LP3I Bandung } \\
\text { tentang strategi bisnis tentang Investasi TI? }\end{array}$ & 3.1 & Level 3 \\
\hline
\end{tabular}




\begin{tabular}{|c|c|c|c|}
\hline No & Proses Val IT & Indeks & $\begin{array}{c}\text { Tingkat } \\
\text { Kematangan }\end{array}$ \\
\hline 11 & $\begin{array}{l}\text { Apakah telah terdapat struktur organisasi } \\
\text { yang telah memiliki koordinasi dan } \\
\text { komunikasi secara jelas? }\end{array}$ & 3.7 & Level 3 \\
\hline \multicolumn{3}{|c|}{ Nilai Indeks VG2 adalah $(3.6+3.6+3.9+3.4+3.1+3.7) / 6=3.5$} & $\begin{array}{l}\text { Level 3 } \\
\text { (Defined) }\end{array}$ \\
\hline \multicolumn{4}{|c|}{ VG.3 Mendefinisikan karakteristik portofolio investasi TI } \\
\hline 12 & $\begin{array}{l}\text { Apakah Politeknik LP3I Bandung telah } \\
\text { memiliki portofolio investasi TI dan dikelola } \\
\text { dengan sesuai prosesnya? }\end{array}$ & 3.3 & Level 3 \\
\hline 13 & $\begin{array}{l}\text { Apakah telah dilakukan pengelompokan atau } \\
\text { pengkategorian investasi IT dalam } \\
\text { portofolionya? }\end{array}$ & 3.1 & Level 3 \\
\hline 14 & $\begin{array}{l}\text { Apakah sudah dibuat dan dikomunikasikan } \\
\text { kriteria evaluasi untuk setiap kategori yang } \\
\text { dilakukan? }\end{array}$ & 3.5 & Level 3 \\
\hline 15 & $\begin{array}{l}\text { Apakah telah ditetapkan bobot untuk setiap } \\
\text { kriteria yang dilakukan? }\end{array}$ & 3.5 & Level 3 \\
\hline 16 & $\begin{array}{l}\text { Apakah telah didefinisikan persyaratan awal } \\
\text { dan detail untuk setiap kategori yang } \\
\text { dilakukan? }\end{array}$ & 3.4 & Level 3 \\
\hline \multicolumn{3}{|c|}{ Nilai Indeks VG3 adalah $(3.3+3.1+3.5+3.5+3.4) / 5=3.4$} & $\begin{array}{l}\text { Level } 3 \\
\text { (Defined) }\end{array}$ \\
\hline \multicolumn{4}{|c|}{$\begin{array}{l}\text { VG.4 Menyelaraskan dan mengintegrasikan nilai manajemen dengan } \\
\text { perencanaan keuangan organisasi }\end{array}$} \\
\hline 17 & $\begin{array}{l}\text { Apakah telah dilakukan pembuatan anggaran } \\
\text { secara keseluruhan tentang Investasi TI? }\end{array}$ & 3.4 & Level 3 \\
\hline 18 & $\begin{array}{l}\text { Apakah dilakukan analisis dampak anggaran } \\
\text { yang dikeluarkan bagi Politeknik LP3I } \\
\text { Bandung dengan pelaksanaan sebenarnya? }\end{array}$ & 3.3 & Level 3 \\
\hline 19 & $\begin{array}{l}\text { Apakah perubahan anggaran dilakukan } \\
\text { dengan prioritas investasi TI? }\end{array}$ & 3.2 & Level 3 \\
\hline 20 & $\begin{array}{l}\text { Apakah perencanaan investasi dilakukan } \\
\text { dengan melihat perencanaan investasi TI yang } \\
\text { telah ada sebelumnya? }\end{array}$ & 3.4 & Level 3 \\
\hline \multicolumn{3}{|c|}{ Nilai Indeks VG4 adalah $(3.4+3.4+3.2+3.4) / 4=3.3$} & $\begin{array}{l}\text { Level } 3 \\
\text { (Defined) }\end{array}$ \\
\hline
\end{tabular}




\begin{tabular}{|c|c|c|c|}
\hline No & Proses Val IT & Indeks & $\begin{array}{c}\text { Tingkat } \\
\text { Kematangan }\end{array}$ \\
\hline \multicolumn{4}{|c|}{$\begin{array}{l}\text { VG.5 Mengidentifikasi kunci dari tujuan proses nilai manajemen untuk } \\
\text { diawasi secara efektif dan dilaporkan. }\end{array}$} \\
\hline 21 & $\begin{array}{l}\text { Apakah ada metrik antara aktivitas dan } \\
\text { ukuran kinerja yang telah disetujui oleh } \\
\text { pimpinan Politeknik LP3I Bandung? }\end{array}$ & 3 & Level 3 \\
\hline 22 & $\begin{array}{l}\text { Apakah proses pengumpulan data untuk } \\
\text { pengawasan tata kelola dilakukan secara tepat } \\
\text { dan efektif? }\end{array}$ & 3.3 & Level 3 \\
\hline 23 & $\begin{array}{l}\text { Apakah telah didefinisikan teknik dan metoda } \\
\text { pelaporan yang dapat memberikan gambaran } \\
\text { bagi Politeknik LP3I Bandung? }\end{array}$ & 3.5 & Level 3 \\
\hline 24 & $\begin{array}{l}\text { Apakah telah dilakukan indentifikasi dan } \\
\text { pengawasan atas aksi-aksi yang dilakukan } \\
\text { manajemen/pelaksana? }\end{array}$ & 3.4 & Level 3 \\
\hline \multicolumn{3}{|c|}{ Nilai Indeks VG5 adalah $(3.0+3.3+3.5+34) / 4=3.3$} & $\begin{array}{c}\text { Level 3 } \\
\text { (Defined) }\end{array}$ \\
\hline & $\begin{array}{l}\text { VG.6 Meningkatkan secara berkala } \\
\text { tentang proses nilai manajemen. }\end{array}$ & & \\
\hline 25 & $\begin{array}{l}\text { Apakah telah dilakukan peningkatan } \\
\text { manajemen nilai dari proses pembelajaran } \\
\text { yang telah dilakukan sebelumnya? }\end{array}$ & 3.3 & $\begin{array}{l}\text { Level } 3 \\
\text { (Defined) }\end{array}$ \\
\hline
\end{tabular}

\section{Hasil Identifikasi Val IT di Politeknik LP3I Bandung}

Analisis yang dilakukan terhadap implementasi investasi teknologi informasi di Politeknik LP3I Bandung maka dilakukan pemetaan terhadap proses-proses Val IT berdasarkan hasil kuesioner yang telah diisi oleh kepada responden kemudian dipetakan ke level model maturity. Pemetaan ini dilakukan agar dapat menjadi acuan bagi pimpinan dan pemangku kepentingan untuk mengetahui sejauh mana proses investasi TI yang telah dilakukan saat ini dan bagaimana upaya untuk meningkatkan proses investasi TI dalam hal ini Sistem Informasi Akademik agar nilai manfaat yang didapatkan sesuai dengan tujuan strategis perusahaan.

Hasil pemetaan analisis keseluruhan proses investasi TI setiap domain Val IT yaitu Sistem Informasi Akademik Politeknik LP3I Bandung dituangkan pada pada gambar 


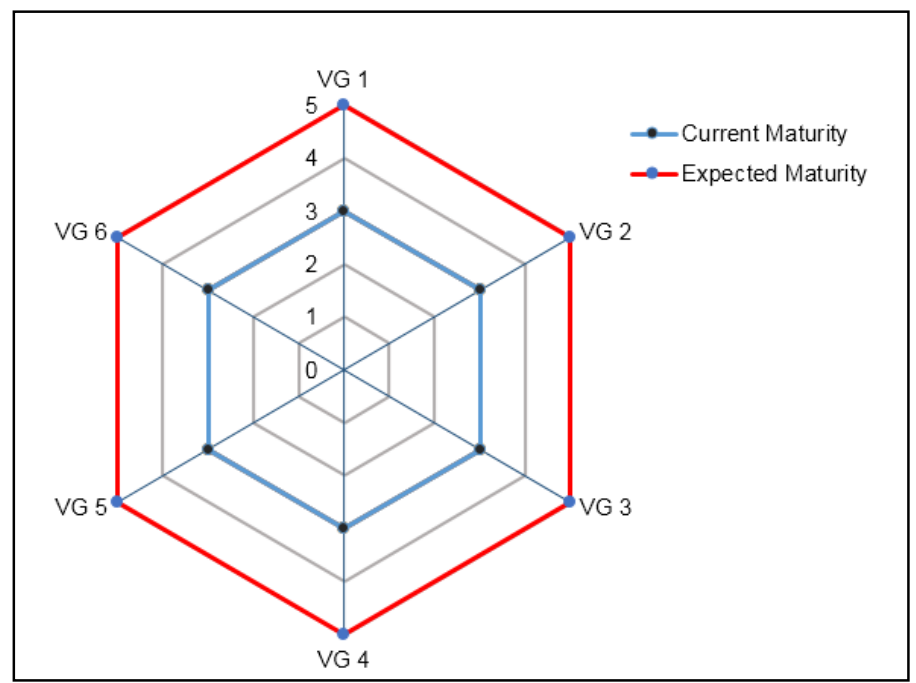

\section{Gambar 4.4 Pemetaan tingkat kematangan Value Governance} di Politeknik LP3I Bandung

\section{Rekomendasi Pelaksanaan Proses Val IT Domain Value Governance}

Berdasarkan hasil analisis identifikasi proses Val IT yang dilakukan melalui level model maturity, maka dibuat rekomendasi bagi pelaksanaan investasi TI yang harus dilakukan Politeknik LP3I Bandung untuk meningkatkan hasil yang optimal dalam pengelolaan investasi TI berdasarkan kerangka kerja Val IT.

Adapun beberapa rekomendasi yang dapat diusulkan berdasatkan hasil kuesioner dan wawancara dengan responden adalah sebagai berikut:

Tabel 4.4 Rekomendasi Pelaksanaan Proses Value Governance

\begin{tabular}{|c|l|l|}
\hline No & \multicolumn{1}{|c|}{$\begin{array}{c}\text { Palue Goves } \\
\text { VG1 Menetapkan } \\
\text { pemberitahuan informasi } \\
\text { tentang Investasi TI dan } \\
\text { pelaksanaan kepepimpinan }\end{array}$} & $\begin{array}{l}\text { Rekomendasi } \\
\text { pemahaman bahwa investasi TI } \\
\text { merupakan potensi strategis yang dapat } \\
\text { diselaraskan dengan tujuan strategis } \\
\text { organisasi dengan cara membuat standard } \\
\text { tata cara pelaporan dan membentuk } \\
\text { forum kepemimpinan yang bertugas } \\
\text { untuk mendefinisikan nilai investasi TI } \\
\text { dan menyelaraskan strategi TI dengan } \\
\text { strategi organisasi. }\end{array}$ \\
\hline 2 & $\begin{array}{l}\text { Pimpinan membuat atau } \\
\text { mengimplementasikan kerangka kerja } \\
\text { tata kelola TI yang dapat dikontrol dan } \\
\text { dinilai oleh Pimpinan Politeknik LP3I } \\
\text { Bandung secara berkala. }\end{array}$ \\
\hline
\end{tabular}




\begin{tabular}{|c|c|c|}
\hline No & $\begin{array}{c}\text { Proses } \\
\text { Value Governance }\end{array}$ & Rekomendasi \\
\hline 3 & $\begin{array}{l}\text { VG3 mendefinisikan } \\
\text { karakteristik portofolio } \\
\text { investasi }\end{array}$ & $\begin{array}{l}\text { Portofolio investasi TI dapat } \\
\text { dikelompokkan menjadi beberapa } \\
\text { kategori dan ditentukan tingkat prioritas } \\
\text { sehingga dapat memudahkan dalam } \\
\text { pengambilan keputusan dan } \\
\text { pendanaannya. } \\
\text { Meningkatkan kriteria evaluasi untuk } \\
\text { setiap kategori untuk memastikan } \\
\text { investasi selaras dengan strategi } \\
\text { organisasi } \\
\text { Jajaran pimpinan Politeknik LP3I } \\
\text { Bandung memberikan pembobotan untuk } \\
\text { setiap kategori portofolio untuk } \\
\text { kepentingan evaluasi. }\end{array}$ \\
\hline 4 & $\begin{array}{l}\text { VG4 menyelaraskan dan } \\
\text { mengintegrasikan } \\
\text { manajemen nilai dengan } \\
\text { perencanaan keuangan } \\
\text { organisasi }\end{array}$ & $\begin{array}{l}\text { Pimpinan dapat memeriksa kembali } \\
\text { bagaimana proses pengaturan anggaran } \\
\text { dan mempertimbangkan apakah business } \\
\text { case tersebut sudah cukup komperehensif } \\
\text { dan lengkap untuk dilakukan. } \\
\text { Jajaran pimpinan harus } \\
\text { mempertimbangkan bagaimana implikasi } \\
\text { dari pembiayaan untuk business case } \\
\text { yang akan dilakukan terhadap tujuan } \\
\text { strategis organisasi. } \\
\text { Pimpinan harus mempertimbangkan } \\
\text { pengelolaan perubahan yang dibutuhkan } \\
\text { pada saat business case dilakukan. }\end{array}$ \\
\hline 5 & $\begin{array}{l}\text { VG5 Membangun } \\
\text { pengawasan tata kelola yang } \\
\text { efektif }\end{array}$ & $\begin{array}{l}\text { Jajaran pimpinan membuat matriks yang } \\
\text { menggambarkan pengukuran antara } \\
\text { aktivitas yang dilakukan dengan hasil } \\
\text { yang didapat. Matriks tersebut juga harus } \\
\text { menggambarkan lead dan lag dari hasil } \\
\text { aktivitas tersebut. } \\
\text { Membuat metode pelaporan yang } \\
\text { menjelaskan mengenai pelaksanaan } \\
\text { program investasi TI. Laporan tersebut } \\
\text { harus terintegrasi dengan fungsi bisnis } \\
\text { yang terkait agar hubungan timbal balik } \\
\text { dapat didefinisikan dengan jelas. }\end{array}$ \\
\hline 6 & $\begin{array}{l}\text { VG6 Meningkatkan praktek } \\
\text { manajemen nilai secara } \\
\text { berkelanjutan }\end{array}$ & $\begin{array}{l}\text { Pimpinan Politeknik LP3I Bandung harus } \\
\text { melakukan peninjauan ulang terhadap } \\
\text { hasil dari manajemen nilai secara rutin } \\
\text { dan perubahan yang diperlukan harus } \\
\text { direncanakan, dilaksanakan dan }\end{array}$ \\
\hline
\end{tabular}




\begin{tabular}{|c|c|c|}
\hline No & $\begin{array}{c}\text { Proses } \\
\text { Value Governance }\end{array}$ & Rekomendasi \\
\hline & & $\begin{array}{l}\text { dimonitor untuk meningkatkan tata kelola } \\
\text { nilai, manajemen portofolio dan proses } \\
\text { manajemen investasi dan prakteknya } \\
\text { sehingga dapat terus meningkatkan } \\
\text { praktek manajemen dan optimalisasi } \\
\text { nilai. }\end{array}$ \\
\hline
\end{tabular}

Dari hasil rekomendasi yang ditunjukkan oleh tabel 4.4, secara umum Politeknik LP3I Bandung harus meningkatkan prosedur tata kelola investasi TI agar investasi TI yang dilakukan dapat direncanakan dengan baik dan juga dapat dievaluasi dan dinilai dengan jelas untuk mencapai nilai investasi TI yang optimal.

\section{Kesimpulan dan Saran}

\subsection{Kesimpulan}

Berdasarkan hasil kajian dan analisis terhadap evaluasi investasi teknologi informasi di Politeknik LP3I Bandung, maka dapat disimpulkan bahwa:

1. Penerapan kerangka kerja Val IT 2.0 dalam manajemen nilai investasi TI melalui salah satu domain yaitu Value Governance di Politeknik LP3I Bandung perlu dilakukan agar nilai manfaat dari investasi TI yang dilakukan yang diinginkan organisasi dapat dicapai. Namun pada pengukuran kinerja manajemen nilai investasi TI berdasarkan tingkat kematangan, Politeknik LP3I Bandung masih berada pada level 3 (Defined) yang berarti bahwa Politeknik LP3I Bandung telah memiliki prosedur baku yang telah baku dan tertulis yang telah dikomunikasikan kepada segenap jajaran manajemen dan staf untuk dipatuhi dan dijalankan dalam aktifitas sehari-hari namun dalam belum sepenuhnya dilakukan secara konsisten.

2. Berdasarkan analisis proses manajemen nilai investasi TI di Politeknik LP3I Bandung, tingkat kematangan proses manajemen investasi TI rata-rata masih berada pada level 3 (Defined). Maka agar dapat memperoleh nilai manfaat yang jelas dan selaras dengan tujuan strategis organisasi diusulkan untuk melaksanakan seluruh proses Val IT 2.0 dalam mengelola investasi TI dan menggunakan Business Case untuk pengembangan program investasi baru.

\subsection{Saran}

Sebagai saran dari hasil kajian dikemukakan sebagai berikut:

1. Pada penelitian ini pengukuran nilai investasi teknologi informasi menggunakan Val IT 2.0 masih fokus terhadap nilai manfaat secara non finansial saja. Diharapkan untuk penelitian selanjutnya penggunaan kerangka kerja Val IT agar menyertakan dengan perhitungan investasi teknologi informasi diintegrasikan dengan pengukuran nilai manfaat secara finansial juga.

2. Politeknik LP3I Bandung diharapkan dapat menerapkan kerangka kerja Val IT agar dapat mengukur sebrapa jauh nilai manfaat dari investasi teknologi informasi yang sudah dilakukan terhadap tujuan strategis perusahaan. Hal ini harus dipahami oleh seluruh pimpinan dan dikomunikasikan kepada seluruh lapisan manajemen agar dapat dipatuhi dan dilaksanakan. 
3. Dalam penelitian ini hanya dilakukan kajian melalui 1 domain saja yaitu Value Governance. Untuk penelitian dengan hasil yang lebih menyelulruh maka dapat dibuat penelitian lanjutan yang mengkaji dari 2 domain lainnya yang terdapat pada kerangka kerja Val IT 2.0 yaitu Portfolio Management dan Investment Management.

\section{Daftar Pustaka}

[1] IT Governance Institute, Enterprise Value: Governance of IT Investments, The Business Case, IT Governance Institute, the United States of America, 2006

[2] IT Governance Institute, Enterprise Value: Governance of IT Investments, The Val IT Framework 2.0 Extract, IT Governance Institute, the United States of America, 2008

[3] IT Governance Institute, Enterprise Value: Governance of IT Investments, The Val IT Framework, IT Governance Institute, the United States of America, 2006

[4] Komalasari, Rita, KERANGKA KERJA VAL IT 2.0 SEBAGAI ALAT PENGUKURAN INVESTASI TEKNOLOGI INFORMASI, Jurnal Teknologi Informasi dan Komunikasi, Bandung, 2014

[5] Latulipe - Rob Singh, Val IT: From the Vantage Point of The COBIT 4.0, Pentagon Model For IT Governance, 2007

[6] Sukmadinata., Metode Penelitian Pendidikan, Remaja Rosdakarya, Bandung. 2006

[7] Tandelilin. Eduardus, Analisis Investasi dan Manajemen Portofolio Edisi. Pertama. Yogyakarta: BPFE Yogyakarta. 2001

[8] Witanti, Wina dan Falahah, VAL IT: KERANGKA KERJA EVALUASI INVESTASI TEKNOLOGI INFORMASI, Seminar Nasional Aplikasi Teknologi Informasi 2007 (SNATI 2007), Yogyakarta, 2007 